\title{
Requirements for Sustainable Irrigated Agriculture
}

\author{
Willibald Loiskandl * and Reinhard Nolz $\mathbb{D}$
}

\begin{abstract}
Vienna (BOKU) Department of Water, Atmosphere and Environment, Institute of Soil Physics and Rural Water Management, Uiversity of Natural Resources and Life Sciences, Vienna (BOKU), Departemen Muthgasse 18, 1190 Vienna, Austria; reinhard.nolz@boku.ac.at

* Correspondence: willibald.loiskandl@boku.ac.at
\end{abstract}

check for

updates

Citation: Loiskandl, W.; Nolz, R. Requirements for Sustainable Irrigated Agriculture. Agronomy 2021, 11, 306. https://doi.org/10.3390/ agronomy11020306

Academic Editor: Alejandro Galindo Received: 22 December 2020

Accepted: 4 February 2021

Published: 9 February 2021

Publisher's Note: MDPI stays neutral with regard to jurisdictional claims in published maps and institutional affiliations.

Copyright: (c) 2021 by the authors. Licensee MDPI, Basel, Switzerland. This article is an open access article distributed under the terms and conditions of the Creative Commons Attribution (CC BY) license (https:/ / creativecommons.org/licenses/by/ $4.0 /)$.

\begin{abstract}
The aim of this review is to present a holistic view on irrigation with respect to local environmental and social conditions. Future irrigation development is addressed with a focus on sustainable development. However, technical irrigation aspects are included and references are provided for further reading and completeness. An irrigation intervention is always a combination of feasible technical, social and environmental aspects. This review provides an overview of the various fields of expertise involved in irrigation interventions and contributes to cross-discipline discussions and understanding. The selected cases demonstrate the bias of human developments and they serve to raise awareness of the impact of human interventions. The practical examples refer mainly to the authors' project experiences and were selected so as to support pathways for sustainable irrigation development. Placing modern irrigation in relation to sustainable development goals needs a sophisticated holistic approach.
\end{abstract}

Keywords: irrigation; sustainable development; agricultural water management; integrated water management

\section{Introduction}

The natural resources soil and water are under increasing pressure worldwide; therefore, the protection of the natural environment must have the highest priority in order to secure adequate food for all and enable sufficient income and living conditions for ensuing generations. Global change impacts are radical with enormous implications. Megatrends like climate change, population growth, urbanization and resource-use conflicts are long-term and intertwined transformation processes that change the lives and livelihoods of people around the world. These trends are not neutral; they cause and contribute to global food price, energy, and fiscal crises. New economic, social, and ecological dynamics tremendously increase the hardships of the vulnerable and the poor [1]. In order to achieve sufficient agricultural production, humankind is interfering in many ways with the natural setting; hence conflicts of resource utilization are present or emerging. A strong partnership amongst all stakeholders is required to confront this. Decision makers (policies) and users (farmers, communities) have to respect each other equally.

Soon after humankind settled and started farming, irrigation appeared as well. During the long period since then, various irrigation methods have been developed and have reached a sophisticated level, especially in terms of technical performance and water applications with respect to plant water requirement. This irrigation development was accompanied by both successes and failures, as is documented by many authors. One of the famous river basins with a long tradition of irrigation lies in the area that was once ancient Mesopotamia. A compilation of information on Mesopotamia-home of irrigation culture-is provided in [2]. In Mesopotamia, irrigation systems were established according to a plan for the first time and a work force was responsible for maintaining the system. However, it has been concluded that the irrigated agriculture of the early Mesopotamian civilisation failed due to salt accumulation from irrigation leading to a degradation of fertile 
land. Mesopotamia is by far the most classical example of glory and decline and today still remains under various stresses. This was also acknowledged in a well-documented study of the Karkheh River Basin, as part of this region, describing historical water development and use from the time of ancient Mesopotamia to third millennium Iran. By performing a trajectory study, Marjanizadeh [3] concluded that: "The Karkheh river basin has been a cradle of civilization for more than 3000 years and has experienced several periods of agrarian development based on settled agriculture and the development of irrigation from the river." The Karkheh River Basin has recently seen extensive development and exploitation of its water resources, leading to severe consequences for the remnants of the internationally renowned Mesopotamian Marshes. A very enlightening compendium of societal development related to climatic changes, resources overuse, and social issues is provided by Diamonds [4]. He analysed worldwide historic developments to judge why some societies have survived and why others have not. It is interesting to note that, especially in northern parts of Europe, the focus in melioration was primarily on drainage and soil water management. This history of melioration in central European countries was elaborated by Kastanek [5]; he named Dünkelberg as a leading pioneer due to his work introducing new agricultural techniques to farmers [6]. Due to the increase of droughts, irrigation has also become more important even in regions where water was considered an ample resource.

To record human-induced changes, new technologies like satellite images have become a direct and invaluable tool for documenting information about spatial development over time, e.g., the change in size of different wetlands. For example, Müller [7] presented satellite images of Lake Aral (including a video animation of the changes from 2000 to 2011, with reference to the shore boundaries of 1960) to visualize its drastic reduction in size. show its drastic reduction in size. What was in the 1960s the fourth largest lake in the world has been reduced to a marginal size due to water withdrawal from the tributaries for irrigation of huge cotton fields in Kazakhstan and Uzbekistan [8]. Nevertheless, the demand of irrigated areas is still growing. The global irrigated area (Figure 1) increased between 1995 and 2018 by more than $40 \%$, from 2,571,753 $\mathrm{km}^{2}[9,10]$ to $3,670,000 \mathrm{~km}^{2}$ [11]; this is approximately $2 \%$ of the total geographical area of the world or $18 \%$ of the arable and permanent cropping area.

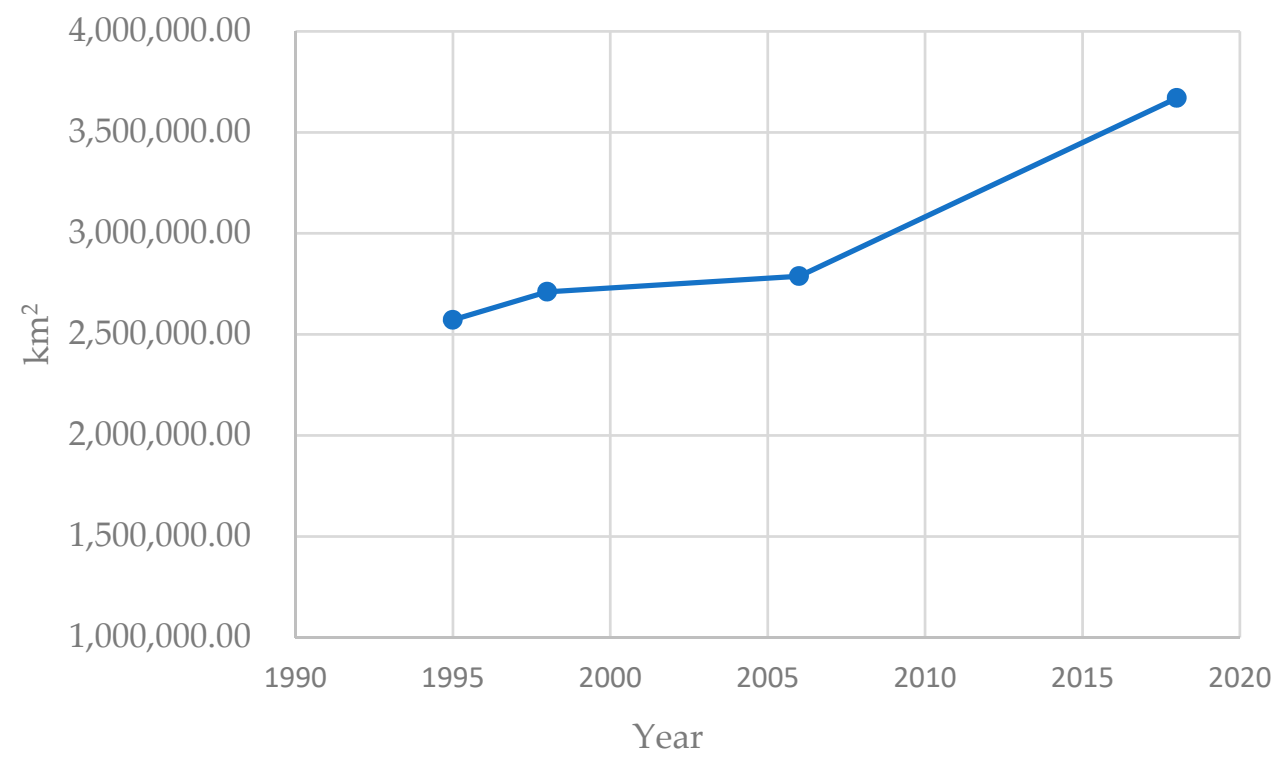

Figure 1. Development of global irrigated area; adapted from [9-11].

A few selected cases are presented here to demonstrate the bias of human developments but could be extended with many more. Here they serve to raise awareness that any intervention has to be undertaken with specific care and in accordance with sustainable 
development-as required by the EU Sustainable Development Goals (SDGs) [12]. Hence, modern irrigation interventions and management need a sophisticated holistic approach.

\section{Aspects of Local and Societal Conditions of Irrigation}

\subsection{Integrated Water Use Analyses}

With the development of societies (in numbers and in welfare), the demand for water increased accordingly; hence integrated water resources management (IWRM) is needed [13-15]). IWMR is a water policy framework mostly applied on a river basin spatial scale. The use of water for irrigation has very well-known figures: it counts for approximately $70 \%$ of global freshwater withdrawal and moreover $85 \%$ of consumptive water use is for irrigation. According to the FAO, irrigated agriculture produces $40 \%$ of the world's food [16].

It is obvious that to obtain water security at a catchment (river basin) level, a legal stewardship is needed. For instance, the EU-WFD (EU Water Framework Directiveintegrated river basin management for Europe) provides a single uniform system of water management for river basins according to natural hydrology and geography [17].

Natural systems are not market-conformed or short-term oriented. Changes occur over long time periods and may be gradual or abrupt, by shocks. Short-term benefits should be dropped in favour of the interests of future generations. This is especially needed when we discuss water management and interventions in any ecosystem in general.

We have the tools to analyse and even forecast the development status of a catchment. Trajectory [18] and water accounting studies [19] describe the course of water utilization in the past, telling us why the situation is like it is at the present stage. Building on this knowledge, a sensitivity analysis of different scenarios may lead to an insight into how a specific decision will most likely affect future development. At the beginning of water resource exploitation, water use is at low level and the potential of development is high (Figure 2). Water allocation is not limited by natural resources. The utilization stage is characterised by interventions in the infrastructure (dams, reservoirs, pumping stations, etc.). Finally, when the water resources are fully committed and the potentially available limit is approached, the allocation stage is reached (Figure 2). It is important to set a threshold value, mainly to take into account reductions of the potentiality of the water resource due to climate change impacts.

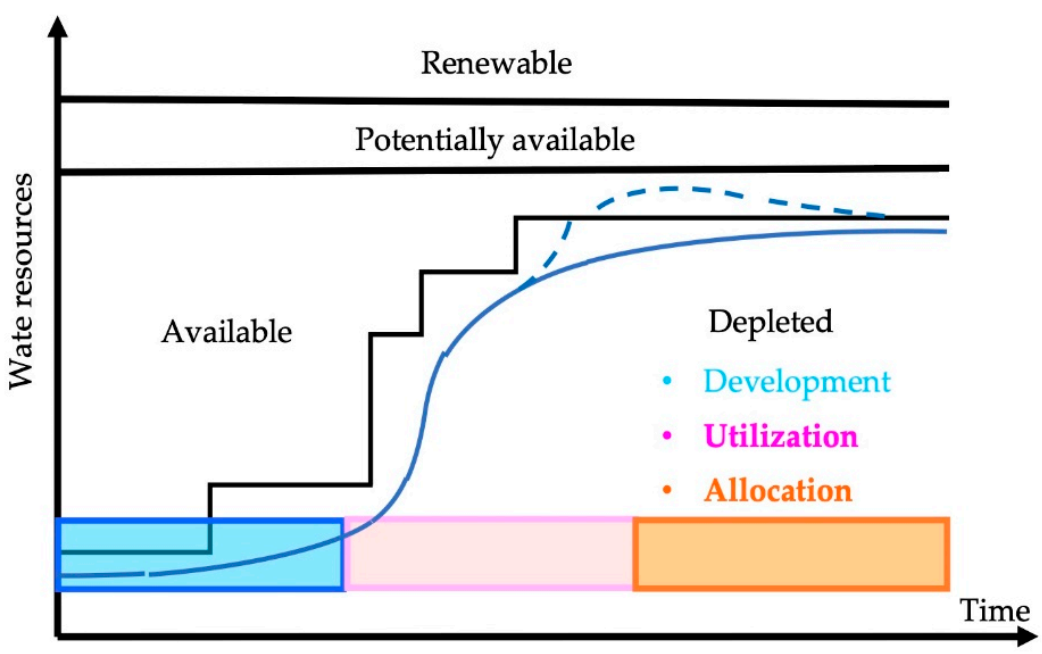

Figure 2. Stages of river basin development (adapted from Molle 2007 [18]). Stepped are e.g., date on certain years, blue is a smoothed function and dashed is an alternative option of water utilization.

Most important is the water utilization with respect to basin closure. In a closed basin, water resources are fully committed to existing uses and all users and uses are interconnected through the hydrological cycle. Further supply augmentation is no longer 
possible without impacting existing uses. The scale for such analyses is mainly the catchment or river basin. Appropriate monitoring must be performed to avoid overexploitation of potential available water resources (Figure 2). In the opinion of the authors, a proper water potential analysis is indispensable for any irrigation intervention, especially in view of sustainability.

\subsection{System-Oriented Characteristics of Irrigation}

Irrigation systems are sociotechnical systems $[14,20]$ embedded in a given natural and economic setting. Special focus should be given to the coordinated interaction of the two components. This is particularly important for irrigation systems, since the "technical" infrastructure of dams, canals, and distribution facilities is often given more attention than the "social" infrastructure represented by institutions (water users) [21].

According to the system orientation characteristics, two features may be highlighted:

- Target-oriented: irrigation systems are used-like all sociotechnical systems-for the provision of certain products or services. The selection of products and services is based on the objectives and interests of those individuals and groups that have influence on the management of the irrigation system.

- Environmentally open: irrigation systems can be characterized as open systems, since the required processes of resource/service provision and resource transformation must take place in close exchange with the environment.

Natural environmental parameters are determined by the Soil-Plant-Atmosphere Continuum (SPAC); more specifically, for irrigation, the crop water requirement (CWR) and hydrological conditions. The other factors are linked to irrigation management. In this frame all components contribute to the success of an irrigation intervention. The weight of the factors may vary according to local conditions.

Related questions to be assessed concerning local and societal conditions include:

- Economic aspects: is an investment beneficial to the prosperity of a community? What economic value is provided in general?

- Irrigation techniques: what techniques are appropriate for a given local setting? How effective is the management structure (both irrigation systems and irrigation management, e.g., decision support tools)? Do the water use efficiency (WUE) and water productivity (WP) match the available resources?

- Sociocultural aspects: what are the consequences of an irrigation intervention for a community? Is there willingness and ability among farmers to introduce new technologies?

- Ecological requirements: what are the environmental flow conditions (e.g., minimal required discharge in a river)? What environmental services in a catchment have to be maintained?

- Administrative aspects: what authorities or institutions are in charge of water distribution and control at the time of investigation? Do water boards exist?

- Legal aspects: what water rights exist? Who possesses ownership of the land? What general legislation exists? What is the status of land ownership?

The different aspects are not only related to the given natural conditions but also directly linked to each other, e.g., economic and technological aspects due to the availability of devices. Ecological and legal aspects are interconnected by water availability, water quality and other facets, as well as being connected to sociocultural conditions. Administration is mainly driven by legal and sociocultural conditions.

Each specific setting has its own dominant requirements, conditions and interferences. To address these aspects at a country level, the water resources and irrigation development in Ethiopia were assessed [22]. The results of this project "Impact of Irrigation on Poverty and Environment" provide a general overview of water resources, a database of irrigation, the utilizable potential of irrigation, and an environmental and health impact assessment [22]. The implementation was done by the International Water Management In- 
stitute (IWMI) and the University of Natural Resources and Life Sciences, Vienna (BOKU), Austria, in collaboration with other Ethiopian and Austrian institutions.

\subsection{Irrigation Management-Resource Utilization}

Irrigation management based on an integrated approach aims to quantify available resources and identify potential uses and users, as well as environmental needs. Managing water for agriculture covers a spectrum from rainfed to irrigated systems-or, in other terms, green and blue water [14]. Such management defines whether full or supplementary irrigation is needed for a given area.

The guiding principles of irrigation management can be summarized as follows:

- integrated management of water resources;

- improvement and safeguarding of water access;

- ensuring evidence-based water policy and management;

- understanding of the interaction of agriculture with the ecosystem;

- inclusion of all stakeholders and provision of transparent decisions;

- improvement of livelihoods and gender equality as pathways to poverty reduction.

Irrigation management has to acknowledge the fact that, due to climate change and overuse, water resources are gradually depleting, soil water storage has been reduced, and soil degradation-due to reduced vegetation cover and secondary salinization—has been increased. To combat soil and land degradation, in many cases traditional or abandoned knowledge can be reintegrated into the relevant society, this being valid for traditional irrigation as well as for rainfed agriculture. Unsuitable land management and cultivation practices combined with climate change lead to a vicious cycle of water scarcity and soil degradation. Under physical water scarcity scenarios-as highlighted in various global studies and assessments [23,24] — and in arid areas, water resources, soil water storage, and water for productive use are naturally limited. Management of these resources, which have a direct impact on soil conditions and microclimates, is of utmost importance if this downward spiral is to be stopped or even reversed. For the Njoro River catchment in Kenya, the interactions between land use/land cover and climate change were analysed to quantify the impact on the local hydrological conditions. The study was performed using SWAT2005 (Soil Water Assessment Tool) [25]. Greater impact was found to result from deforestation than overall climate change at the time of investigation. The results provide the basis for strategies of adaption to the changing environmental conditions.

Water scarcity forces on-farm conservation practices, like storing water above ground or in soil, and alternative ways of water utilization. Irrigation water is deployed for multiple uses-e.g., for fisheries-in many countries in Africa [26]. The reuse of waste water is another water source which may become even more important in the future [27]. Irrigation increases the salt content of soils and it is estimated that about $25 \%$ to $30 \%$ of irrigated land is affected by this [28]. For salt-affected soils, specific management is required [29]. On the other hand, water scarcity also triggers discussions about the use of water of poorer quality and in particular has led to a discussion of so-called saline agriculture. Especially in countries with a high population growth rate and/or severe rates of soil degradation, the use of brackish water could substantially contribute to food security and poverty reduction [30]. Montague [31] estimated a doubling of available water for agriculture if all of the world's brackish water were used for irrigation.

Finally, irrigation management is-besides its roles in handling water utilization, allocation, conservation, maintenance, etc.-strongly linked to conflict avoidance and resolution. Conflicts start with a contradiction, e.g., competition for water in an irrigation system or inefficient water distribution, both of which have a strong impact on farmers. Attitudes determine the visible behaviours of farmers and communities. An attitude covers the thoughts, feelings and centres of perception of a rural community [32] in response to the consensus of farmers and management with regard to allocation and distribution of water. The system of canals and structures should be clearly understood by the farmer community. Behaviour summarizes the visible components of a conflict; in the worst cases 
this can include destructive actions, like destruction of infrastructure, denial of allocation, and so on. Well-managed farmer associations result in constructive cooperation amongst members.

Galtung [33] presented the social conflict factors-behaviour, contradiction and attitudein a triangle (Figure 3) to distinguish the visible and invisible components. Like an iceberg, most contributions to conflicts are invisible.

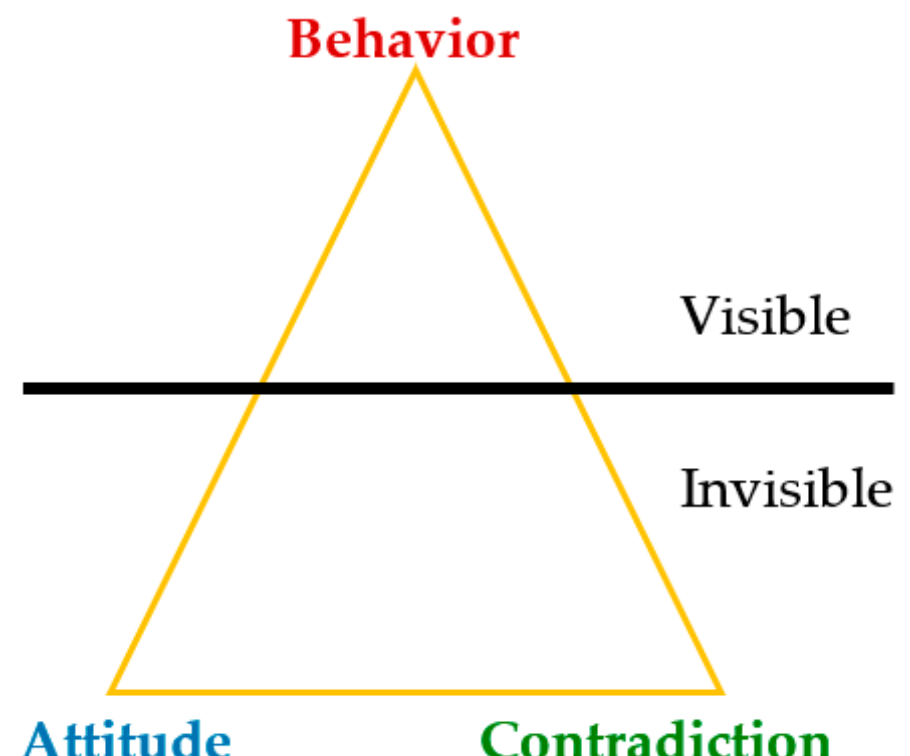

Figure 3. Conflict triangle according to Galtung [34].

\section{Options for Agricultural Water Management and Resources Management}

\subsection{Improving Soil and Soil Water Conditions}

In a changing world - due to climate change and human intensification of land usesoil water management is still of growing importance [34]. Soil involves that part of the hydrological water cycle where water interacts with soil. In the hydrological glossary of UNESCO [35], soil water is defined as a subsystem of the hydrology of a river basin. Further, soil water management is determined by the prevailing conditions and dynamics in the basin. Subsurface water (soil water and groundwater) constitutes the majority of the volume of terrestrial water resources. For soil water, Gusev and Novak [36] distinguished three major functions in terrestrial ecosystems:

- "Soil water is the most active link in the interchange of continental waters,

- Soil water is an element of the global climatic system (owing to its location at the atmospherelithosphere interface, soil water notably contributes to the formation of climate),

- Soil water is the most important factor governing the existence and development of the vegetation cover, which is the basic link in the trophic chain of land ecosystem."

Management also has to acknowledge that soil water transports solutes (e.g., nutrients and contaminants) and influences chemical and biological processes. Therefore, water quality aspects are also part of soil water management activities.

In a field-scale setting, it is obvious that agricultural practice has three major intervention entry points (Figure 4):

- irrigation;

- $\quad$ field management (tillage, plant selection, agricultural practise, etc.);

- $\quad$ the supply of inputs (nutrients, weed and disease control). 


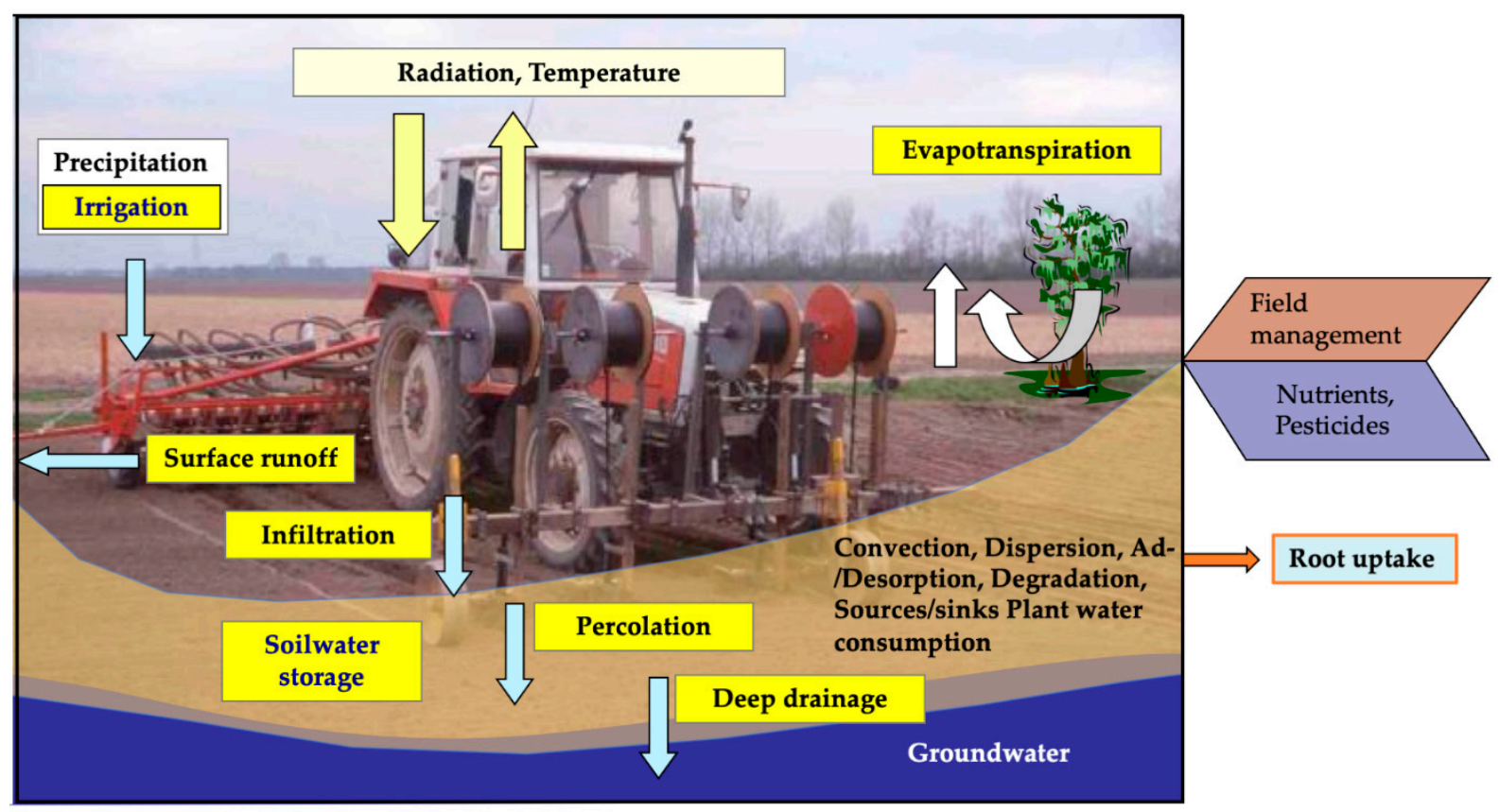

Figure 4. Agricultural land setting for irrigation: implementing subsurface drip irrigation.

In this respect, water management (e.g., run-off reduction) and land-use practises (e.g., soil fertility improvement) are equally important. Land use and cover changes impact the local hydrology (e.g., soil water storage) and are one of the factors responsible for changes of the microclimate.

Irrigation complements crop water demand or supplies water as full irrigation for crop production. Agricultural practise aims to minimise surface runoff, enhance infiltration and soil water storage, and control percolation and deep drainage. As important as land utilization is the selection of crops. The planted crops directly influence the evapotranspiration and hence determine the water demand. The way that field tillage is performed is an especially major issue. On the one hand, there are traditional practises such as ploughing and intensive field preparation; on the other hand, opposite to the traditional approach, there is conservation agriculture (CA) with minimum soil disturbance. CA is based on the three pillars of no tillage, soil cover (cover crops or mulching), and crop rotation. CA is beneficial to soil fertility and soil health under many agroecological conditions [37].

Plant roots are one of the key players below ground. They generally act as sinks but, for some substances, may also act as sources. In the last decades, most attention was paid to the plant parts above ground and to an increase of yield and optimised nutrient supply. Due to changes of environmental conditions and limited water resources, the breeding of drought-tolerant plants and the root system came into focus again [38]. Many investigations (e.g., $[39,40]$ ) have shown that even varieties of a species show significant differences in the root system. This was strongly emphasised for wheat with regard to the so-called "Green Revolution" [41].

In another study with durum-wheat, Triticum turgidum ssp. durum-and peasPisum sativum - significant differences between species were also presented [42,43]. The origins of genotypes proofed as important factors leading to these differences. The genotypes from dry regions reflect the development of a significantly stronger root system and higher drought tolerance. This does not necessarily imply a higher yield but it does open options for breeding with respect to increased stress tolerance and stable yield. To demonstrate and visualize this, winter wheat (Triticum aestivum) of the Capo (Figure 5, left) and Midas (Figure 5, right) varieties was grown in a Rhizobox [38]. The more intensive root development, with a greater depth, can clearly be seen for the Capo variety. 

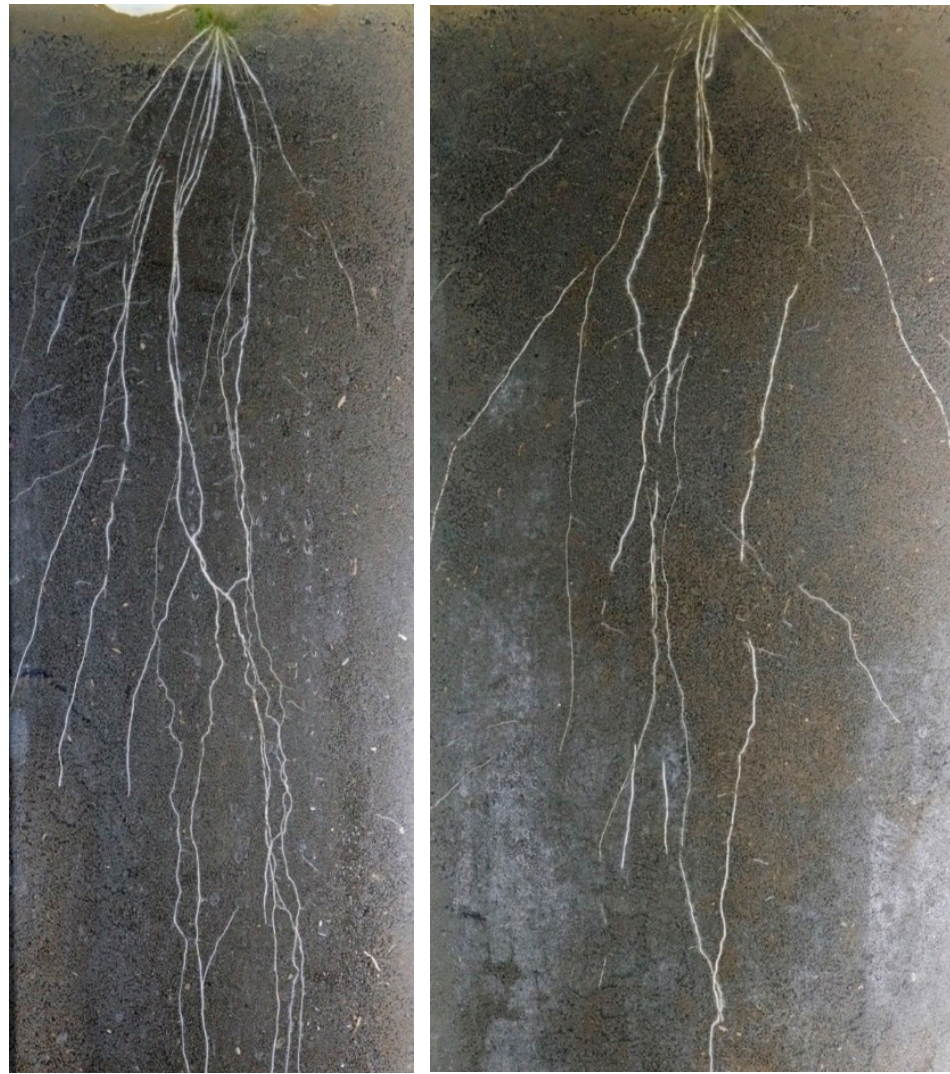

Figure 5. Root development of winter wheat (Triticum aestivum) varieties after three weeks' development in a Rhizobox. (left): Capo; (right): Midas (Image: BODNER 2020, [38]).

Breeding achievements can be assessed by satellite-based observation; e.g., WangErlandsson et al. presented an "earth observation-based" method for estimating the root zone storage capacity using state-of-the-art satellite-based evaporation observations [44].

Beyond the field scale, on-farm strategies are bound to catchment conditions. The management of a catchment was successfully demonstrated in Northern Ethiopia, Tigray. A series of small dams (Figure 6 left), runoff-stopping structures (Figure 6 right), and reforestation were implemented [45]. As a result, flooding in the valley was reduced and the water storage in the catchment, especially in the valley floor, was improved. This led to an extension of the growing time and also enabled the production of alternative crops.
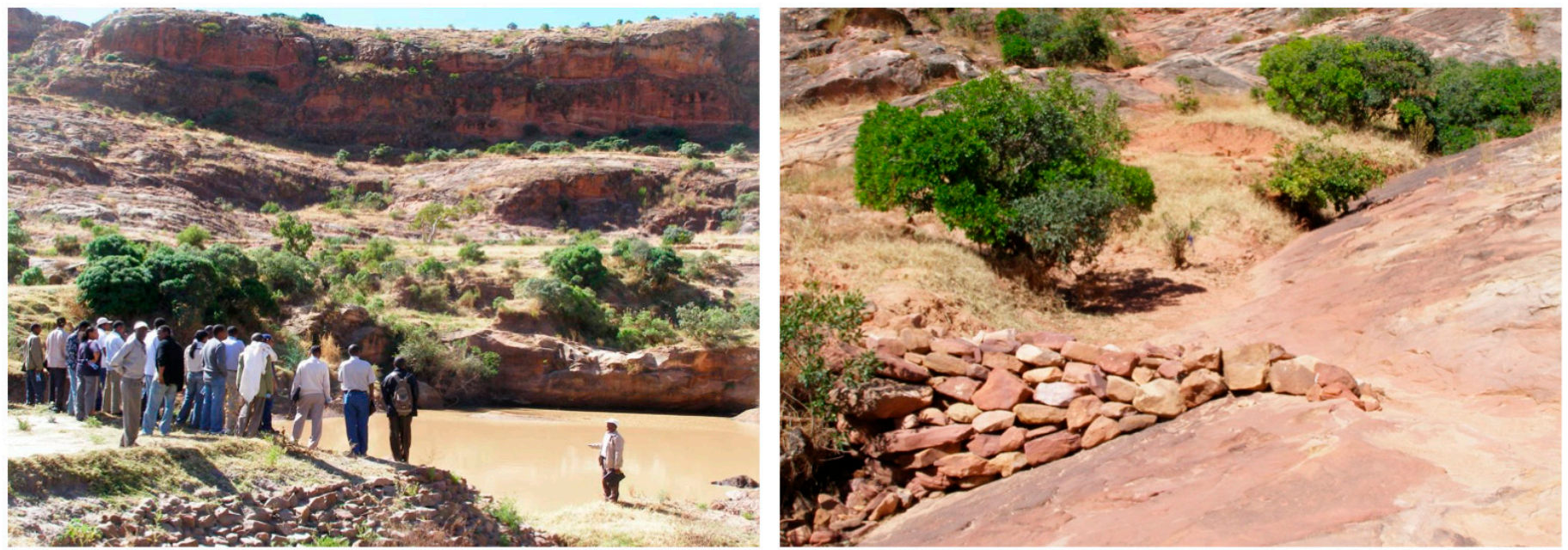

Figure 6. Catchment interventions. (left): small dam, (right): runoff-stopping structure. Tigray, Ethiopia [45]. 


\subsection{Water Application and Irrigation Systems}

Once the hydrological conditions and the potential of available resources have been quantified, ascertaining the way to irrigate is the next logical step. Irrigation is practiced in different ways. Generally, any additional water application may be referenced to as irrigation, from water supply in gardening systems to large-scale irrigation schemes, e.g., centre pivot machinery. A summary of irrigation techniques is presented in Table 1, followed by descriptions of the most common systems. To demonstrate the variability of local conditions (social, hydrological, economic and others), examples are provided referring to different grades of technical standards. Irrigation is a well-documented topic and numerous publications are available. The FAO provides comprehensive information in a series of irrigation manuals [46-50]. The material is divided into 14 modules. Further, especially practical, information can be obtained in twenty related training manuals at the FAO homepage [51]. A very concise book on surface irrigation by Kay is available [52].

Surface irrigation systems apply water to the soil surface through an overland water flow regime due to gravity. To this group belong basin, border (border strip), and furrow irrigation. Surface irrigation has the longest tradition as an agricultural practice and represents the most common type worldwide. The conveyance system is often similar in most surface systems-either an open-channel or a pipe system. To establish a basin irrigation system, a certain area of land is levelled and surrounded by earth dams. Such basins can be of rectangular or irregular shape (Figure 7). The water is then distributed within the basin as uniformly as possible.

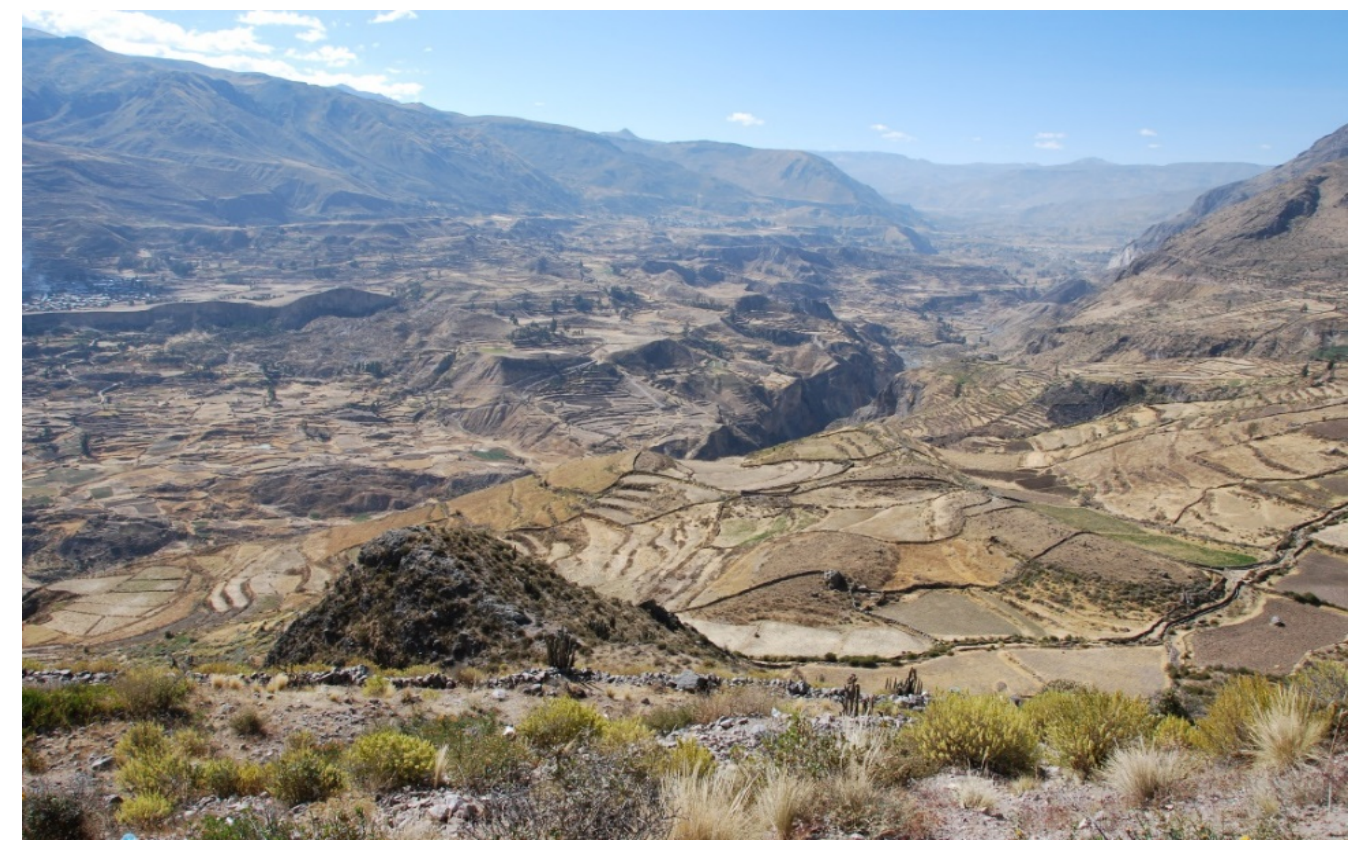

Figure 7. Traditional surface irrigation, Colca river valley, Peru (example of an "irregular shape").

For furrow irrigation, the soil surface is formed as a dam-and-furrow-sequence, with plants growing on the dams while water is distributed along the furrows. The shape, spacing, and length of dams and furrows depend on the type of crop (preferably row crops) and soil. Border strips are separated by small earth bunds for guiding water flow down the field. This kind of irrigation requires a certain slope and a proper levelling of the surface that allows an even distribution of the water across the field. A drainage system is required at the bottom of a border strip plot. One simple technology used to irrigate involves opening and closing earth canals with simple tools and diverting seasonal flood water to fields (Figure 8). 
Table 1. Overview of irrigation techniques.

\begin{tabular}{|c|c|c|}
\hline & Principle/Design & Comments/Types \\
\hline Surface irrigation & \multicolumn{2}{|c|}{ Application of water to the soil surface by gravity } \\
\hline Basin irrigation & Levelled or nearly levelled fields surrounded by bunds & Rectangular shape or contour basins \\
\hline Furrow irrigation & Levelled or sloped fields with the surface prepared as furrows and dams & $\begin{array}{l}\text { Corrugation: special form where small channels guide the water across } \\
\qquad \text { a field }\end{array}$ \\
\hline Flood irrigation & Fields without flow controls such as furrows or borders & Alternative term: wild flooding \\
\hline Sprinkler irrigation & \multicolumn{2}{|c|}{ Application of water onto the crop via a system of sprinkler nozzles with water delivered by pipelines under pressure } \\
\hline Periodic-move sprinkler systems & $\begin{array}{l}\text { Portable quick-coupling laterals or hose reels that can be moved from one } \\
\text { location to another }\end{array}$ & E.g., hand-move laterals, side-roll laterals, traveling gun, traveling boom \\
\hline Fixed sprinkler systems & $\begin{array}{l}\text { A network with enough pipes and sprinkler heads to complete irrigation } \\
\text { in one place }\end{array}$ & $\begin{array}{l}\text { Either with solid-set portable laterals (removed before harvest) or } \\
\text { permanent laterals (buried) }\end{array}$ \\
\hline Continuous-move sprinkler systems & $\begin{array}{l}\text { Motorized laterals with sprinklers that irrigate and continuously move at } \\
\text { the same time }\end{array}$ & $\begin{array}{l}\text { Centre pivot } \\
\text { Linear moving systems }\end{array}$ \\
\hline Drip lines & $\begin{array}{l}\text { Surface or subsurface laterals (lay-flat, flexible, or semirigid tubing) with } \\
\text { uniformly spaced point-source emitters }\end{array}$ & Emitters with pressure-compensating hydraulic microstructures \\
\hline Sprayers or mini-sprinklers & $\begin{array}{l}\text { Water is distributed via mini sprinklers in full or partial circle patterns of } \\
\text { small diameters }\end{array}$ & \\
\hline Subirrigation & \multicolumn{2}{|c|}{$\begin{array}{c}\text { Application of water below the ground surface by raising the water table to the root zone or by using a buried perforated pipe system to apply water } \\
\text { within the root zone (not to be confused with subsurface drip irrigation) }\end{array}$} \\
\hline
\end{tabular}

Table adapted from: FAO Irrigation Manual, Module 1, Chapter 3 [46] and NRCS NEH 652 Irrigation Guide. 


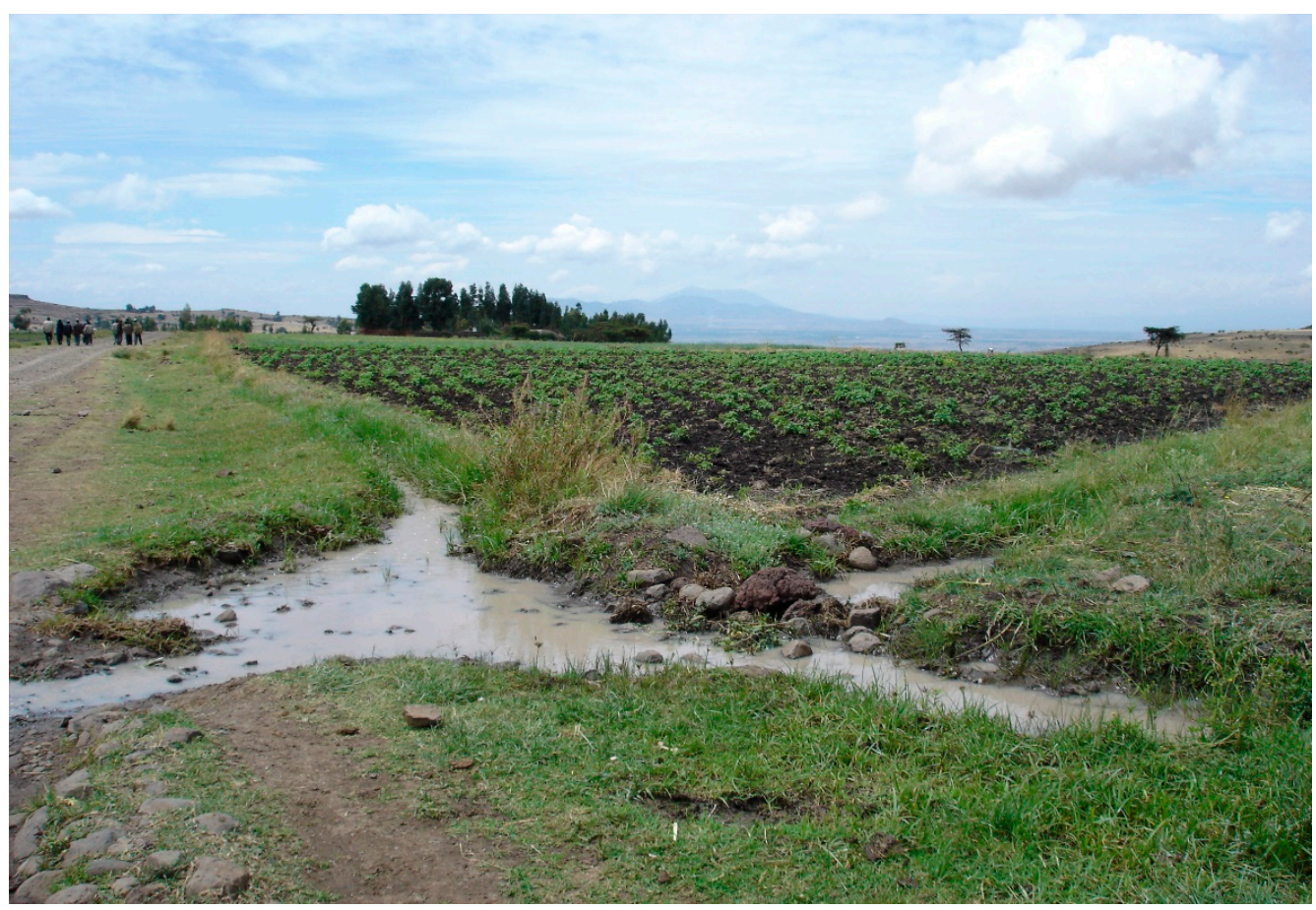

Figure 8. Spate irrigation, highlands, Ethiopia.

It is well-known that surface irrigation systems are particularly prone to unproductive losses of water. On the one hand, this includes evaporative losses arising from the large water surface and wetted surface. On the other hand, deep percolation losses occur if flooding is insufficiently adapted to crop water requirements and soil properties. Therefore, proper operation is of particular importance for surface irrigation. Various detailed descriptions of how to plan, design, operate, and maintain surface irrigation systems are available; see, for example, the Irrigation Manual Vol. II Module 3. Furthermore, hydrodynamic modelling can be used to plan and optimise basin irrigation systems [53]. Barrios-Masias and Jackson [54], for instance, combined furrow irrigation with a deficit irrigation strategy to increase water productivity.

Sprinkler irrigation systems transport and distribute water through pressurized pipe networks before sprinkling it onto the land like natural rainfall. Sprinkler systems can be stationary - operating with sprinklers in a fixed position (Figure 9) - or operate while moving, like centre pivot systems or hose reel systems with a rain gun (Figure 10). The main evaporation losses occur when sprinkler systems are operated under suboptimal conditions, such as high wind velocities and high air temperatures during daytime [55]. Several techniques, such as wireless sensor networks or remote communications, are available to (partly) automatize the operation of sprinkler irrigation and simplify and optimise irrigation scheduling (e.g., [56]). Variable rate irrigation is an approach based around the better adaptation of sprinkler intensities to crop water requirements and soil characteristics $[57,58]$. In such a way, irrigation efficiency and crop water productivity can be increased.

Drip irrigation (Figure 11) and subsurface drip irrigation-the latter with the laterals buried in the ground-represent the most efficient systems. The main reason is that the water is applied via emitters near or within the main rooting zone without wetting plant leaves or large areas of the soil surface. In this way, unproductive loss can be reduced to a minimum, provided that a proper strategy is implemented. Drip irrigation systems can be precisely adopted to crop water requirements and soil characteristics; for example, by varying emitter spacing and irrigation strategy [59-61]. Like for the other irrigation systems, several studies addressing the adaption and optimisation of drip irrigation strategy have been published in recent years. Common approaches for developing and improving irriga- 
tion management include calculating crop water requirements (e.g., [62]), monitoring soil water status (e.g., [63,64]), combining soil water balancing and soil sensing (e.g., $[65,66])$, and monitoring canopy temperature (e.g., $[67,68])$. Also, an experimental approach involving cosmic-ray neutron sensing for drip irrigation scheduling can be found in recent literature [69]. The overall objective of these studies is to maximise water productivity, which can be achieved by increasing irrigation efficiency (reducing unproductive losses) and at the same time stabilising yield.

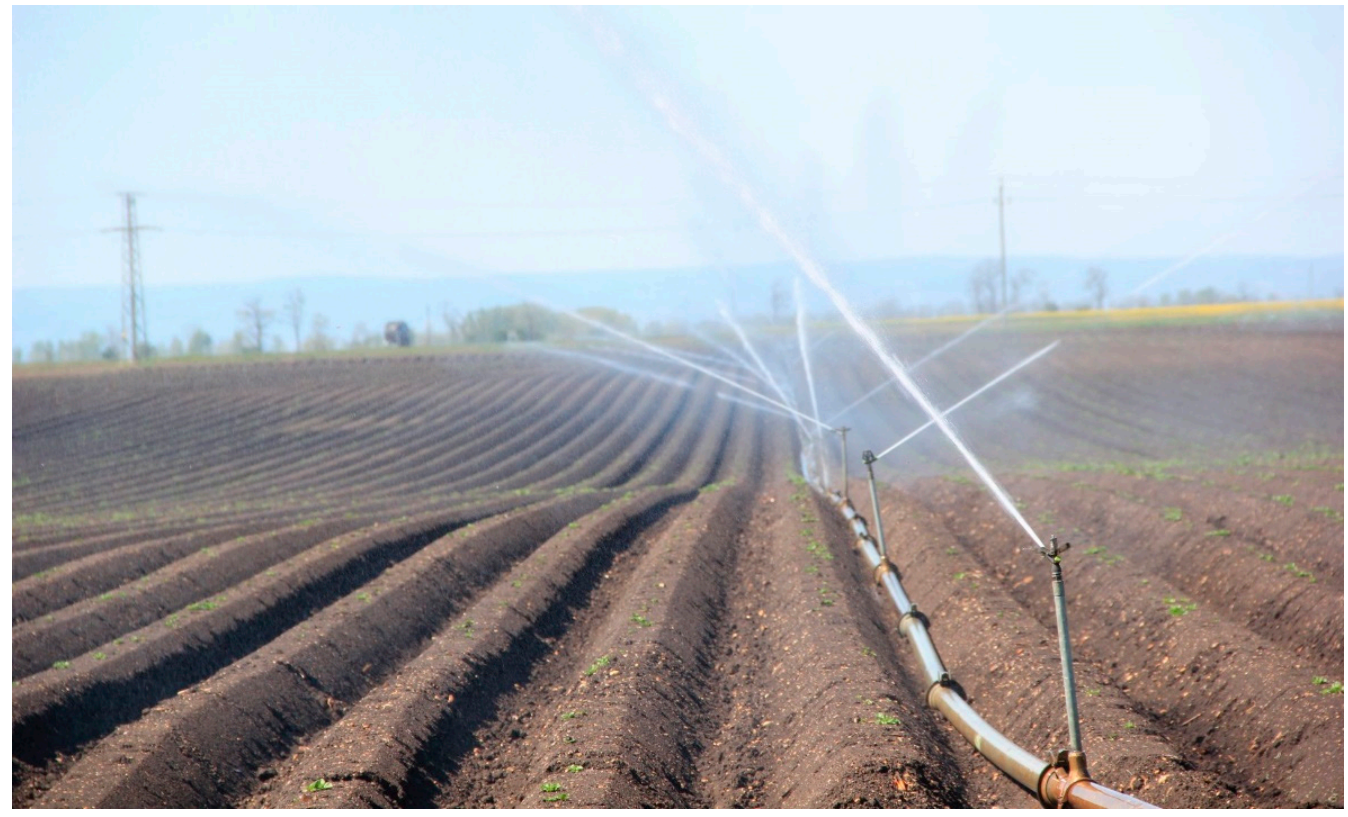

Figure 9. Sprinkler irrigation and germination of potatoes, north-eastern Austria.

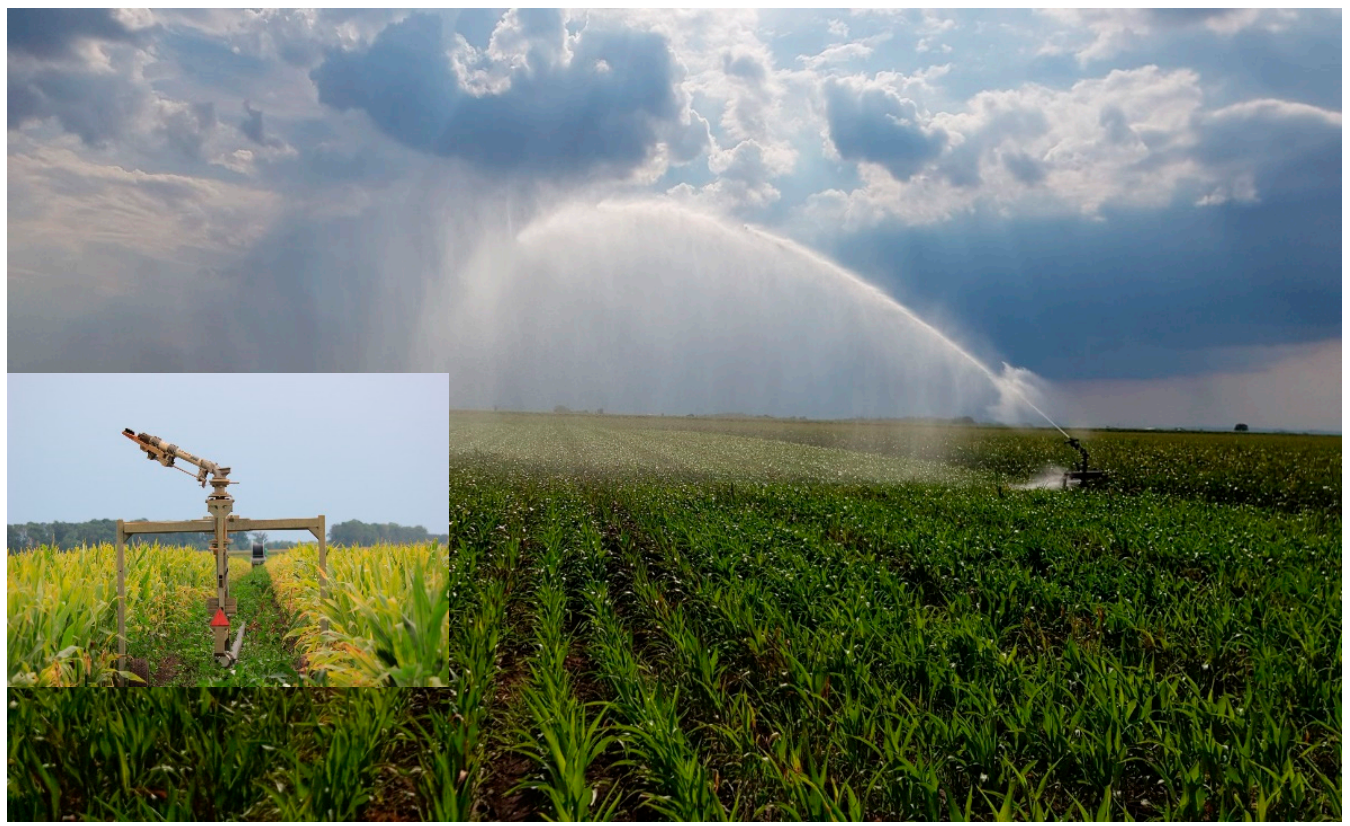

Figure 10. Rain gun, in operation and in detail and maize, north-eastern Austria.

Drip irrigation is not only practised where there are no financial limits. Simple arrangements also enable smallholder farmers in underprivileged parts of the world to apply water conservation techniques at low costs (Figure 12). This was demonstrated as part of the WATERMAN dissemination project $[45,70]$ sponsored by EU. Water can be 
lifted with a treadle pump to a raised tank (Figure 12 top) or simply stored in a bucket (Figure 12 bottom) and then distributed to the field or raised bed, respectively.

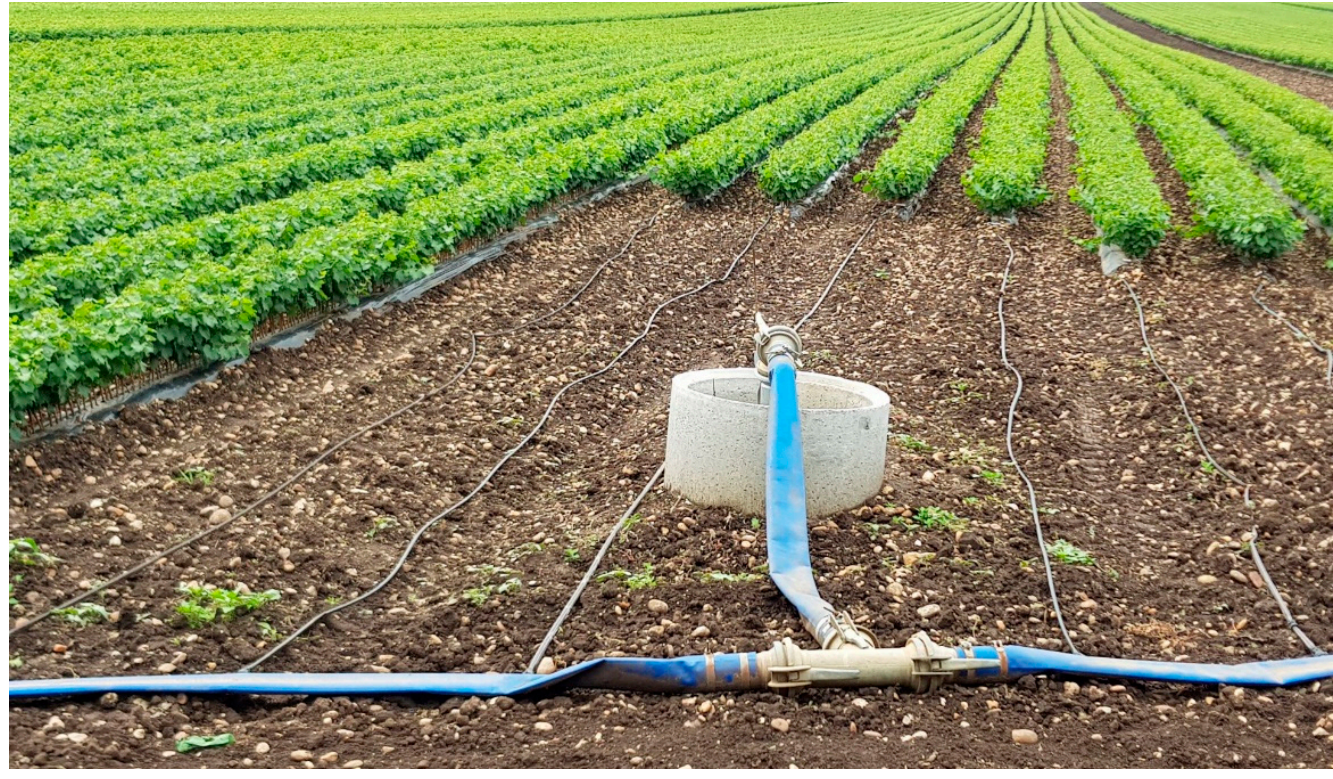

Figure 11. Drip irrigation, viticulture nursery, north-eastern Lower Austria.
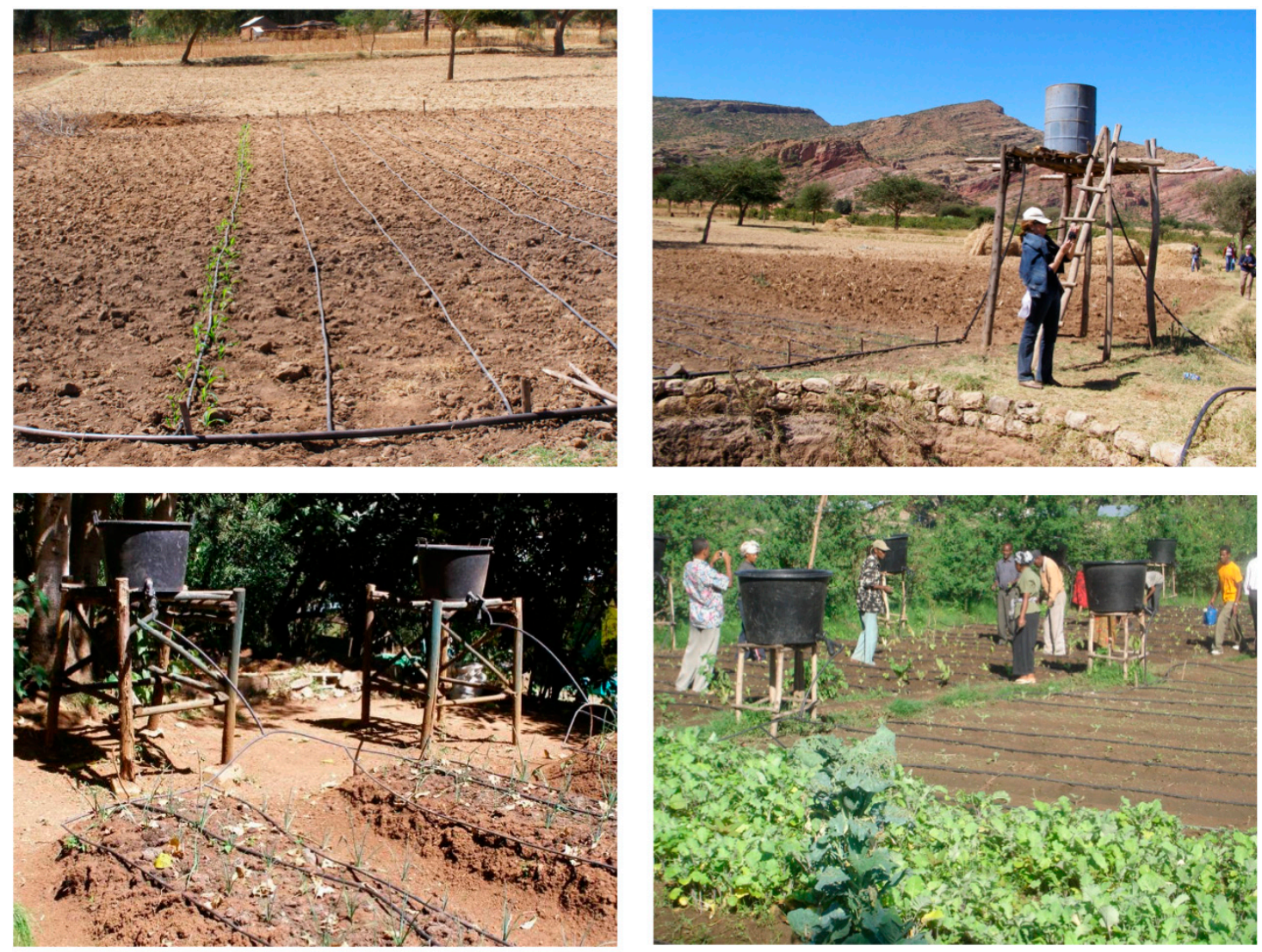

Figure 12. Simple drip irrigation, Ethiopia [45]. Top Tigray, left: drip line, top right: storage tank, bottom left and right: demonstration of a simple bucket and drip line set up during a dissemination workshop in Awassa, Sidama. [70].

Efficient use of water is particularly important in irrigated agriculture. Relations between water inputs and biomass production (or related outputs) can be described in many 
ways, as reviewed by Nair et al. [71]. In agronomy, the term water use efficiency (WUE) is typically used to express the relationship between crop yield per unit area and the water used to produce that yield per unit area [71,72]. From a technical point of view, one way that WUE can be related to an irrigation system is in terms of conveyance efficiency and distribution efficiency [71]. In this context, irrigation systems can be evaluated based on their general characteristics and improved by reducing application losses. Irmak et al. [73] indicated that potential application efficiencies of surface irrigation range between 45 and $80 \%$, given that the irrigation system is well-designed and well-managed. Under such conditions, sprinkler irrigation systems were expected to be $65-90 \%$ efficient, with micro-irrigation systems being the most efficient, having rates between 80 and 95\% [73]. Wang et al. [74] achieved a considerably larger WUE with drip irrigation compared to border irrigation. They also found an increase of nitrogen use efficiency (NUE). An increase of both WUE and NUE when optimising drip irrigation was also found by Trifonov et al. [75]. However, WUE essentially depends on several factors, including crop management and irrigation scheduling [72].

Due to climate change effects also occurring in environments where water was not previously seen as a limiting factor, the use of water and resources has become of higher importance in many places worldwide. This has led to the cooperation of the Papua New Guinean National Agricultural Research Institute (NARI) and its Southern Pacific partners (Solomon Islands and Vanuatu) with European partners, sponsored by the EU-ARD (European Union programme for Agricultural Research for Development) framework. The project was concerned with the generation, validation, and dissemination of innovative agricultural technologies, the mitigation of climate change-imposed risks to food production and hence to food security, and livelihoods and economic development in Papua New Guinea (PNG), Solomon Islands (SI), and Vanuatu (Vu) [76]. Water utilization was one of the priority areas. Through a rural appraisal, the water accessibility and the current water use and management in target communities in PNG, SI, and Vu were identified [76]. Furthermore, a strategy for integrated water management for each target group based on the rural appraisal assessments, local hydrological water balances, and water accounting was developed. Finally, in drought-vulnerable parts of PNG, SI, and Vu, water harvesting methods, groundwater availability, irrigation techniques, and water conservation strategies were assessed. During the project time, the utilization of readily available resources (hardware, material from scrapyards, and locally grown bamboo) was demonstrated in Lee (PNG). Figure 13 shows a simple groundwater lifting system (rope and washer pump) combined with a bamboo drip irrigation line that was demonstrated during an agricultural field day in 2015. All material was locally available and easily assembled [77]. All the aspects raised in this paper were inherent parts within this project.

\subsection{Deficit Irrigation}

Traditional approaches to irrigation management often aim at increasing agricultural production by maximising yield, which can result in disproportionately high application of water. As mentioned earlier, considering crop water requirements and soil water status for irrigation scheduling is an important step towards sustainable water resources management. As a development of this demand-oriented approach, the FAO promotes the slogan "more crop per drop", especially with respect to irrigation in water-scarce areas. This initiative is based on the concept of maximising crop water productivity (WP) [79]. In this respect, water productivity indicates a relationship between plant productivity and water use; hence, it expresses the quantity of output (e.g., harvested yield) in relation to the volume of water consumed $[71,80]$.

Ways to increase WP include opting for crops with high WP-especially in dry regionsor breeding genotypes with high WP. Another way to increase WP is proper on-farm management of irrigation [81]. Furthermore, combining efficient irrigation technology and best management practices can result in a very efficient use of water resources [82]. 

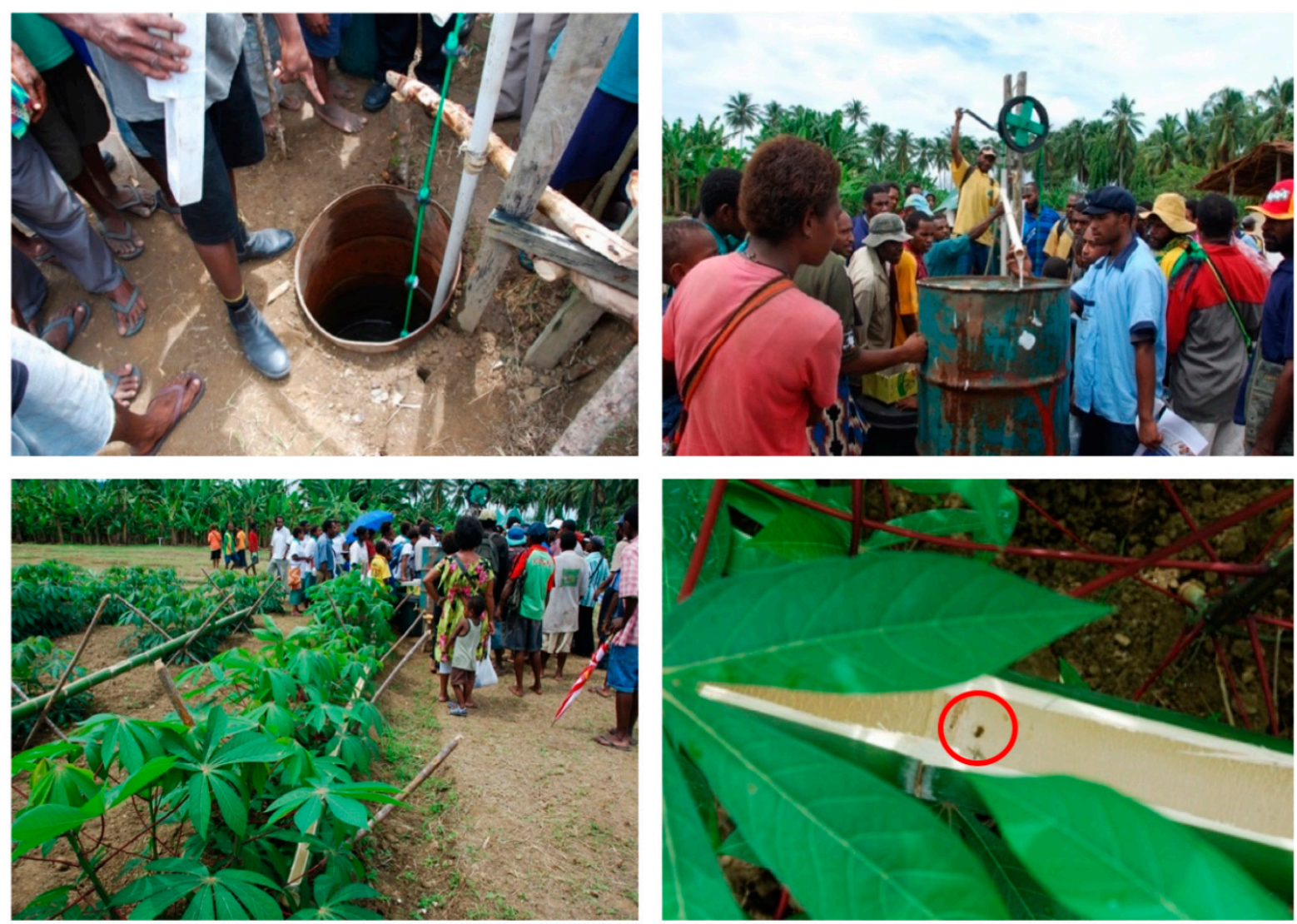

Figure 13. Drip irrigation in Papua New Guinea. top left: Well, top right: rope and washer pump, bottom left: bamboo supply lines, bottom right: dripper hole [78].

Deficit irrigation is an optimising strategy in accordance with this notion. It has been widely investigated as a valuable approach for dry regions (e.g., [83]). The basic approach involves only guaranteeing optimal water supply during sensitive crop growth stages, whereas drought stress is to some extent tolerated during less sensitive crop development stages, e.g., the vegetative phase or late ripening. Hence, a slight yield decrease is accepted while aiming at the stabilisation of yields and maximisation of WP. Despite the risk of production losses, deficit irrigation has often proved to not only save water but also increase economic benefits due to the reduction of costs, mainly in dry regions [83,84]. However, this is not a general statement because environmental and economic boundary conditions are complex and highly dynamic. Besides the influence on biomass production and crop yields, deficit irrigation has often been shown to have a positive effect on crop quality, especially for tree crops and vines [83]. In such cases, economic returns are larger. According to Fereres and Soriano [83] and Montazar et al. [85], further research is recommended to investigate the long-term effects of deficit irrigation.

From a more technical point of view, deficit irrigation strategies require detailed knowledge of crop development, sensitive growth stages, environmental conditions, and plant or soil water status $[54,83,84,86]$. Thus, monitoring devices such as micrometeorological sensors, surface temperature sensors, or soil water sensors are required. In this context, proximal and remote sensing technologies have recently been developed that can obtain spatial information about plant water status as represented by indices such as the normalised difference vegetation index (NDVI) or the crop water stress index (CWSI) [87,88]. Determining the drought sensitivity of a certain crop during a season or a particular growth stage is a demanding and long-term task as it often also depends on genotype and location. Geerts and Raes [79] have summarized various experimental findings on the sensitivity of 
different crops to drought stress. They recommend combining field measurements with crop modelling to further improve deficit irrigation strategies.

Although deficit strategies are often associated with drip irrigation-as this combination represents the most efficient method of irrigating-Barrios-Masias and Jackson [54], for instance, have combined partial root-zone drying with furrow irrigation. Partial root-zone drying maintains half of the root system under drying conditions while the other half is provided with better access to soil water. In such a way, water use efficiency can be increased. This case study highlights another way of applying a deficit strategy to implement a surface irrigation method in a more sustainable way.

\subsection{Water Banking}

The way that water banking is commonly addressed implies two meanings [89]:

(1) aquifer storage and recovery (ASR);

(2) the assignment of an economic value to water storage.

Long-term water storage in an aquifer and groundwater recovery are two options to remediate water excess withdrawal or climate change impacts on temporal rainfall distribution. In comparison with storage basins, underground water storage is not related to land and evaporation losses. Depending on water quality, underground storage may require a sophisticated conceptualization of treatment before water can be made to infiltrate into so-called seepage fields.

In a groundwater basin in eastern Austria, near Vienna, water is diverted from the Danube by a canal and used for groundwater recharging and other purposes [90]. This region (Marchfeld) is considered one of the most valuable areas of arable land in Austria, having the best soil types, like chernozem, but prone to droughts. To ensure groundwater withdrawal for irrigation and other purposes, water is infiltrated if the quality is acceptable, pre-treated, and infiltrated again under control (Figure 14).

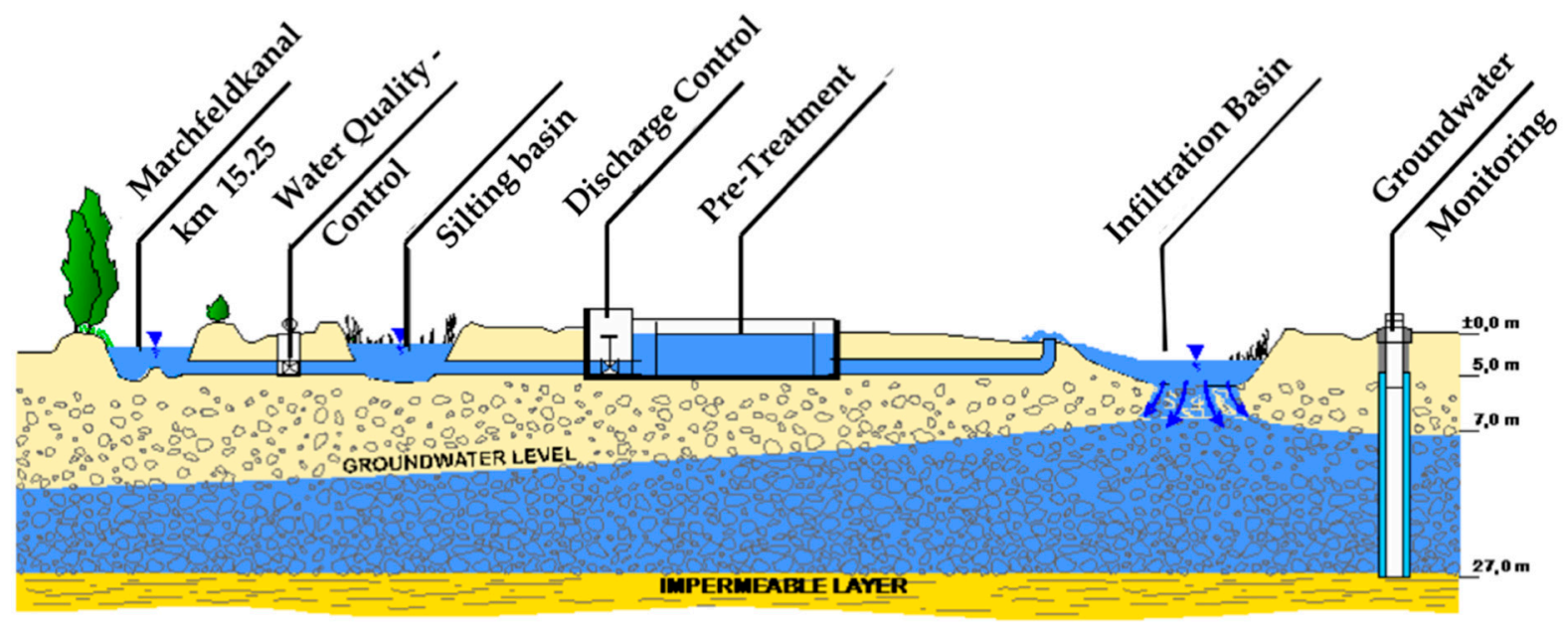

Figure 14. Operation scheme of groundwater recharge in eastern Austria (Marchfeld) to combat decline of groundwater head [86].

Recharge of aquifers using seasonal excess surface water contributes to the mitigation of downstream flooding and increased groundwater storage. As previously, this serves to enable agricultural production during the dry season and enhance drought resilience. Alam et al. [91] identified suitable areas for underground transfer of floods for irrigation (UTFI) on a global scale. The Benefits would not only be for irrigation but also for co-management of floods and droughts at the river basin scale. A related option is groundwater dams, in which an artificial (hydraulic structure) or natural obstacle holds groundwater in an aquifer [92]; however, high construction costs are often a limiting factor for these projects. 
The term "banking" indicates the economic value of water. Pratt [93] was one of the first to introduce the concept of water banking. A working definition was provided by Singletary [94]: "Water banking is a tool for leasing water for a limited period of time on a voluntary basis between willing water rights holders and users". Water banking provides temporary transfers of water entitlements. Depending on the need of a user for water, and also when it is needed, water is transferred without affecting existing water rights. The individual decides to lease water according to personal perception. Similarly to currency saving or exchanging through monetary banks, water banking is a choice. Water-banking transactions take place without the threat of outside coercion and operational needs require that water be assigned a current market value, which in turn requires that the water input and the risks and costs involved in the transaction are agreed upon.

\section{Conclusions}

Various tools, like trajectory studies, water accounting, and public participation, have been proven as successful utilities for better capturing the complexities of water use in river basins. Indispensable for an integrated approach is the involvement of all stakeholders in securing a better future and a liveable environment for all. Even the best analyses will not acquire an environmentally sound result if the acceptance of an intervention at the policy or farm level is missing.

Sustainable irrigated agriculture is based on an efficient use of resources, supported by innovative tillage practises, crop rotation, cover cropping, soil amendments, and plant selection. For the optimal use of available water, irrigation and drainage practices must be bound to innovative irrigation techniques and management. Applications at the farm and basin levels are equally dependent on technical, social, and economic conditions.

Neglect of the process of basin closure by overdevelopment of irrigation infrastructure is a negative experience mirrored in many countries. In many irrigation interventions a proper feasibility study is often overruled by economic or political decisions. However, for sustainable development—as defined by the SDGs and agreed by most people- the purely economically driven approach should become a relic of the past.

Author Contributions: Both authors contributed equally to the writing of the paper. The first author delivered most of the international case studies and the second author shared his experience of irrigation practices in Austria. Both authors have read and agreed to the published version of the manuscript.

Funding: This investigation received no external funding.

Institutional Review Board Statement: Not applicable.

Informed Consent Statement: Not applicable.

Data Availability Statement: All data resources are referenced in the paper, no other reference used.

Conflicts of Interest: The authors declare no conflict of interest.

\section{References}

1. Hauser, M.; Loiskandl, W.; Wurzinger, M. Innovation Systems Research Sustainable Natural Resource Use in Least Developed Countries. GAIA 2011, 20, 70-72. [CrossRef]

2. Facts and Details. AGRICULTURE: Crops, Irrigation and Livestock in Mesopotamia, Agriculture in Mesopotamia. 2020. Available online: http:/ / factsanddetails.com/world/cat56/sub363/item1513.html\#chapter-0 (accessed on 10 December 2020).

3. Marjanizadeh, S.; Qureshi, A.S.; Turral, H.; Talebzadeh, P. From Mesopotamia to the Third Millennium: The Historical Trajectory of Water Development and Use in the Karkheh River Basin, Iran; IWMI Working Paper 135; International Water Management Institute: Colombo, Sri Lanka, 2009; p. 51. [CrossRef]

4. Diamond, J. Collapse. How-Societies Choose to Fail or Succeed; Viking, Penguin Group: New York, NY, USA, 2005.

5. Kastanek, F. Die Tradition der Kulturtechnik. Wien. Mitt. Wasser Abwasser Gewässer Band 1998, 149, 1-59.

6. Dünkelberg, F. Der Landwirth als Techniker; Friedrich Vieweg und Sohn: Braunschweig, Germany, 1865.

7. Müller, M. Wie der Aralsee zur Menschengemachten Katastrophe Wurde. Wirtschaftswoche \#38. 26 February 2020. Available online: https: / / www.wiwo.de/technologie/wirtschaft-von-oben/wirtschaft-von-oben-38-aralsee-wie-der-aralsee-zurmenschengemachten-katastrophe-wurde/25583934.html (accessed on 11 December 2020). 
8. Lexas, Geographie, Erde. Available online: https://www.lexas.de/seen/aralsee/index.aspx (accessed on 11 December 2020).

9. Siebert, S.; Döll, P.; Hoogeveen, J.; Faures, J.M.; Frenken, K.; Feick, S. Development and validation of the global map of irrigation areas. Hydrol. Earth Syst. Sci. 2005, 9, 535-547. Available online: www.copernicus.org/EGU/hess/hess/9/535 (accessed on 16 November 2005). [CrossRef]

10. Siebert, S.; Henrich, V.; Frenken, K.; Burke, J. Update of the Digital Global Map of Irrigation Areas (GMIA) to Version 5. 2013, Institute of Crop Science and Resource Conservation; Rheinische Friedrich-Wilhelms-Universität: Bonn, Germany, 2013.

11. Meier, J.; Zabel, F.; Mauser, W. A global approach to estimate irrigated areas-A comparison between different data and statistics. Hydrol. Earth Syst. Sci. 2018, 22, 1119-1133. [CrossRef]

12. United Nations Sustainable Development Goals. 17 Goals to Transform Our World. Available online: https://www.un.org/ sustainabledevelopment (accessed on 11 December 2020).

13. Molden, D. Accounting for Water Use and Productivity; SWIM Paper 1; International Irrigation Management Institute: Colombo, Sri Lanka, 1997.

14. Molden, D. (Ed.) Water for Food, Water for Life: A Comprehensive Assessment of Water Management in Agriculture; EarthScan: London, UK; International Water Management Institute (IWMI): Colombo, Sri Lanka, 2007.

15. Bouwer, H. Integrated Water Management: Emerging Issues and Challenges. Agric. Water Manag. 2000, 45, 217-228. [CrossRef]

16. Water in Agriculture-World Bank Group. Available online: https://www.worldbank.org/en/topic/water-in-agriculture (accessed on 21 January 2021).

17. EU-WFD, Directive 2000/60/EC of the European Parliament and of the Council Establishing a Framework for the Community Action in the Field of Water Policy. Available online: https:/ / ec.europa.eu/environment/water/water-framework/index_en.html (accessed on 10 December 2020).

18. Molle, F. Development Trajectories of River Basins: A Conceptual Framework; Research Report No 72; IWMI: Colombo, Sri Lanka, 2003; Available online: http:/ / www.iwmi.cgiar.org/pubs/pub072/Report72.pdf (accessed on 11 December 2020).

19. Molle, F.; Weste, P.; Hirsch, P. River basin development and management. In Water for Food, Water for Life: A Comprehensive Assessment of Water Management in Agriculture; David, M., Ed.; EarthScan: London, UK, 2007; Chapter 16.

20. Mcloughlin, I.; Badham, R.; Couchman, P. Rethinking Political Process in Technological Change: Socio-technical Configurations and Frames. Technol. Anal. Strateg. Manag. 2000, 12, 17-37. [CrossRef]

21. Quast, J. Local Actions within Rural Water Management-Building Blocks in a Framework for Integrated River Basin Management. In Soil Physics and Rural Water Management_-Progress, Needs and Challenges, Proceedings of the International Symposium SoPhyWa, Vienna, Austria, 28-29 September 2006; Kammerer, G., Kastanek, F., Eds.; University of Natural Resources and Applied Life Sciences: Vienna, Austria, 2006; pp. 3-6. ISBN 3-900963-65-0.

22. Awulachew, S.B.; Yilma, A.D.; Loulseged, M.; Loiskandl, W.; Ayana, M.; Alamirew, T. Water Resources and Irrigation Development in Ethiopia; Working Paper 123; International Water Management Institute: Colombo, Sri Lanka, 2007; p. 78.

23. Petruzzello, M. Water Scarcity. Encyclopædia Britannica. 14 April 2020. Available online: https://www.britannica.com/topic/ water-scarcity (accessed on 19 December 2020).

24. Water Scarcity Atlas. An Introduction to Water Scarcity, Showcasing Global Analyses. Available online: https://waterscarcityatlas. org (accessed on 19 December 2020).

25. Mwetu, K.K. Modeling Responses of Hydrology to Land Use-Land Cover Change and Climatic Variabilit: A Case Study in River Njoro Catchment of Kenya. Ph.D. Thesis, University of Natural Resources and Life Sciences, Vienna, Austria, 2010.

26. Melcher, A.; Ouedraogo, R.; Oueda, A.; Somda, J.; Toe, P.; Sendzimir, J.; Slezak, G.; Voigt, C. SUSFISHBook-Sustainable Fisheries and Water Management. 2020; Transformation Pathways for Burkina Faso. SUSFISH+ Project Consortium. Available online: http:/ / susfish.boku.ac.at/ (accessed on 30 January 2015).

27. IWMI (International Water Management Institute). Wastewater Reuse in Numbers: Making the Most of Agriculture's Only Expanding Resource; CGIAR Research Program on Water, Land and Ecosystems (WLE): Colombo, Sri Lanka, 2017; p. 8.

28. Shahid, S.A.; Zaman, M.; Heng, L. Soil Salinity: Historical Perspectives and a World Overview of the Problem. In Guideline for Salinity Assessment, Mitigation and Adaptation Using Nuclear and Related Techniques; Springer: Cham, Switzerland, 2018. [CrossRef]

29. FAO. salinity_brochure_en. Management of Irrigation-Induced Salt-Affected Soils. Available online: http://www.fao.org/ tempref/agl/agll/docs/salinity_brochure_eng.pdf (accessed on 18 December 2020).

30. Ladeiro, B. Saline. Agriculture in the 21st Century: Using Salt Contaminated Resources to Cope Food Requirements. Hindawi Publ. Corp. J. Bot. 2012, 2012. [CrossRef]

31. Montague, H. Saline Agriculture has the Power to Change (and Feed) the World. IHE Delft. The Netherlands Stories. November 2020. Available online: https:/ / www.un-ihe.org/stories/saline-agriculture-has-power-change-and-feed-world, (accessed on 18 December 2020).

32. Floch, P. Water User Associations as Means of Preventing and Dealing with Conflicts. Master's Thesis, Institute of Hydraulics and Rural Water Management, University of Natural Resources and Life Science, Vienna, Austria, 2004.

33. Galtung, J. Conflict Transformation by Peaceful Means (The Transcend Method); UN Disaster Management Training Program: Geneva, Switzerland, 2000.

34. Loiskandl, W.; Kammerer, G. Soil Water Management. In Encyclopedia of Agrophysics; Glinski, J., Horabik, J., Lipiec, J., Eds.; Springer Science+BusinessMedia B.V.: Dortrecht, The Netherlands, 2011. [CrossRef] 
35. UNESCO. (Ed.) International Glossary of Hydrology. 2009. Available online: http://webworld.unesco.org/water/ihp/db/ glossary/glu/EN/GF1380EN.HTM (accessed on 22 December 2020).

36. Gusev, Y.; Novak, V. Soil water-main water resources for terrestrial ecosystems of the biosphere. J. Hydrol. Hydromech. 2007, 55, 3-15.

37. Kaweesa, S.H. Adoption of Conservation Agriculture in Uganda. Ph.D. Thesis, University of Natural Resources and Life Sciences, Vienna, Austria, 2020.

38. Bodner, G. Sortenwahl. In Pflanzenwurzeln, Wurzeln Begreifen, Zusammenhänge Verstehen; Sobotik, M., Eberwein, R.K., Bodner, G., Stangl, R., Loiskandl, W., Eds.; DLG-Verlag, Frankfurt/Main: Frankfurt am Main, Germany, 2020; p. 316. ISBN 978-3-7690-0855-5.

39. Chloupek, O.; Forster, B.P.; Thomas, W.T. The effect of semi-dwarf genes on root system size in field-grown barley. Theor. Appl. Genet. 2006, 112, 779-786. [CrossRef]

40. Manschadi, A.M.; Hammer, G.L.; Christopher, J.T. Genotypic variation in seedling root architectural traits and implications for drought adaptation in wheat (Triticum aestivum L.). Plant Soil 2008, 303, 115-129. [CrossRef]

41. Waines, J.G.; Ehdaie, B. Domestication and crop physiology: Roots of green-revolution wheat. Ann. Bot. 2007, 10, 991-998. [CrossRef]

42. Nakhforoosh, A.; Grausgruber, H.; Kaul, H.P.; Bodner, G. Wheat root diversity and root functional characterization. Plant Soil 2014, 380, 211-229. [CrossRef]

43. Zhao, J.; Bodner, G.; Rewald, B. Phenotyping: Using machine learning for improved pairwise genotype classification based on root traits. Front. Plant Sci. 2016, 7, 1864. [CrossRef]

44. Wang-Erlandsson, L.; Bastiaanssen, W.G.M.; Gao, H.; Jägermeyr, J.; Senay, G.B.; Van Dijk, A.I.J.M.; Guerschman, J.P.; Keys, P.W.; Gordon, L.J.; Savenije, H.H.G. Global root zone storage capacity from satellite-based evaporation. Hydrol. Earth Syst. Sci. 2016. [CrossRef]

45. WATERMAN. 6th Framework Programme, INCO-CT-2006-031694, Coordinator: Loiskandl, W. In Proceedings of the 4th Workshop Report: “Water Management and Irrigation” Focus on Groundwater, Mekelle, Ethiopia, 3-5 December 2007.

46. FAO Irrigation Manual. Planning, Development, Monitoring E Evaluation of Irrigated Agriculture with Farmer Participation; Sub-Regional Office for Eastern and Southern Africa (SAFR) Harare: Harare, Zimbabwe, 2002; Volume I, Module 1-6; ISBN 0-7974-2316-8.

47. FAO Irrigation Manual. Planning, Development, Monitoring $\mathcal{E}$ Evaluation of Irrigated Agriculture with Farmer Participation; SubRegional Office for Eastern and Southern Africa (SAFR) Harare: Harare, Zimbabwe, 2002; Volume II, Module 7; ISBN 0-79742315-X

48. FAO Irrigation Manual. Planning, Development, Monitoring \& Evaluation of Irrigated Agriculture with Farmer Participation; SubRegional Office for Eastern and Southern Africa (SAFR) Harare: Harare, Zimbabwe, 2001; Volume III, Module 8; ISBN 0-79742318-4.

49. FAO Irrigation Manual. Planning, Development, Monitoring E Evaluation of Irrigated Agriculture with Farmer Participation; Sub-Regional Office for Eastern and Southern Africa (SAFR) Harare: Harare, Zimbabwe, 2002; Volume IV, Module 9; ISBN 0-7974-2317-6.

50. FAO Irrigation Manual. Planning, Development, Monitoring E Evaluation of Irrigated Agriculture with Farmer Participation; Sub-Regional Office for Eastern and Southern Africa (SAFR) Harare: Harare, Zimbabwe, 2002; Volume V, Module 9; ISBN 0-7974-2319-2.

51. FAO Training Manuals. Available online: http://www.fao.org/home/search/en/?q=Irrigation\%20training\%20manuals (accessed on 18 December 2020).

52. Kay, M. Surface Irrigation: Systems and Practice; Cranfield University Press: Cranfield, UK, 1990; p. 150. ISBN 100947767266.

53. Khanna, M.; Malano, H.M. Modelling of basin irrigation systems: A review. Agric. Water Manag. 2006, 83, 87-99. [CrossRef]

54. Barrios-Masias, F.H.; Jackson, L.E. Increasing the effective use of water in processing tomatoes through alternate furrow irrigation without a yield decrease. Agric. Water Manag. 2016, 17, 107-117. [CrossRef]

55. Sadeghi, S.H.; Peters, T.; Shafii, B.; Amini, M.Z.; Stöckle, C. Continuous variation of wind drift and evaporation losses under a linear move irrigation system. Agric. Water Manag. 2017, 182, 39-54. [CrossRef]

56. Zhu, X.; Chikangaise, P.; Shi, W.; Chen, W.; Yuan, S. Review of Intelligent Sprinkler Irrigation Technologies for Remote Autonomous System. Int. J. Agric. Biol. Eng. 2018, 11, 23-30. [CrossRef]

57. Sharma, V.; Irmak, S. Comparative analyses of variable and fixed rate irrigation and nitrogen management for maize in different soil types: Part I. Impact on soil-water dynamics and crop evapotranspiration. Agric. Water Manag. 2020, 106644. [CrossRef]

58. Sui, R.; O'Shaughnessy, S.A.; Evett, S.R.; Andrade, M.A. Evaluation of a decision support system for variable-rate irrigation in a humid region. Trans. ASABE 2020, 63. [CrossRef]

59. Bajpai, A.; Kaushal, A. Soil moisture distribution under trickle irrigation: A review. Water Supply 2020, 20, 761-772. [CrossRef]

60. Trifonov, P.; Lazarovitch, N.; Arye, G. Increasing water productivity in arid regions using low-discharge drip irrigation: A case study on potato growth. Irrig. Sci. 2017, 35, 287-295. [CrossRef]

61. Shabbir, A.; Mao, H.; Ullah, I.; Buttar, N.A.; Ajmal, M.; Lakhiar, I.A. Effects of Drip Irrigation Emitter Density with Various Irrigation Levels on Physiological Parameters, Root, Yield, and Quality of Cherry Tomato. Agronomy 2020, 10, 1685. [CrossRef]

62. Abuarab, M.E.; Hafez, S.M.; Shahein, M.M.; Hassan, A.M.; El-Sawy, M.B.; El-Mogy, M.M.; Abdeldaym, E.A. Irrigation scheduling for green beans grown in clay loam soil under a drip irrigation system. Water $S A$ 2020, 46, 573-582. 
63. Cormier, J.; Depardieu, C.; Letourneau, G.; Boily, C.; Gallichand, J.; Caron, J. Tensiometer-based irrigation scheduling and water use efficiency of field-grown strawberries. Agron. J. 2020, 112, 2581-2597. [CrossRef]

64. Millán, S.; Casadesús, J.; Campillo, C.; Moñino, M.J.; Prieto, M.H. Using Soil Moisture Sensors for Automated Irrigation Scheduling in a Plum Crop. Water 2019, 11, 2061. [CrossRef]

65. Domínguez-Niño, J.M.; Oliver-Manera, J.; Girona, J.; Casadesús, J. Differential irrigation scheduling by an automated algorithm of water balance tuned by capacitance-type soil moisture sensors. Agric. Water Manag. 2020, 228, 105880. [CrossRef]

66. Studer, C.; Spoehel, S. Potential and Actual Water Savings through Improved Irrigation Scheduling in Small-Scale Vegetable Production. Agronomy 2019, 9, 888. [CrossRef]

67. Khorsand, A.; Rezaverdinejad, V.; Asgarzadeh, H.; Majnooni-Heris, A.; Rahimi, A.; Besharat, S. Irrigation scheduling of maize based on plant and soil indices with surface drip irrigation subjected to different irrigation regimes. Agric. Water Manag. 2019, 224, 105740. [CrossRef]

68. Kirnak, H.; Irik, H.A.; Unlukara, A. Potential use of crop water stress index (CWSI) in irrigation scheduling of drip-irrigated seed pumpkin plants with different irrigation levels. Sci. Hortic. 2019, 256, 108608. [CrossRef]

69. Li, D.; Schrön, M.; Köhli, M.; Bogena, H.; Weimar, J.; Jiménez Bello, M.A.; Han, X.; Gimeno, M.A.; Zacharias, S.; Vereecken, H.; et al. Can Drip Irrigation be Scheduled with Cosmic-Ray Neutron Sensing? Vadose Zone J. 2019, 18, 190053. [CrossRef]

70. WATERMAN. 6th Framework Programme, INCO-CT-2006-031694, Coordinator: Loiskandl, W. In Proceedings of the 3rd WORKSHOP REPORT: "Water Supply and Integrated Water Resources Management", Awassa, Ethiopia, 25-27 April 2007.

71. Nair, S.; Johnson, J.; Wang, C. Efficiency of irrigation water use: A review from the perspectives of multiple disciplines. Agron. J. 2013, 105, 351-363. [CrossRef]

72. Howell, T. Enhancing water use efficiency in irrigated agriculture. Agron. J. 2001, 93, 281-289. [CrossRef]

73. Irmak, S.; Odhiambo, L.O.; Kranz, W.L.; Eisenhauer, D.E. Irrigation Efficiency and Uniformity, and Crop Water Use Efficiency; University of Nebraska-Lincoln Extension: Lincoln, NB, USA, 2011. Available online: http://ianrpubs.unl.edu/epublic/live/ec7 32/build/ec732.pdf (accessed on 14 January 2021).

74. Wang, Y.; Li, S.; Liang, H.; Hu, K.; Qin, S.; Guo, H. Comparison of Water- and Nitrogen-Use Efficiency over Drip Irrigation with Border Irrigation Based on a Model Approach. Agronomy 2020, 10, 1890. [CrossRef]

75. Trifonov, P.; Lazarovitch, N.; Arye, G. Water and Nitrogen Productivity of Potato Growth in Desert Areas under Low-Discharge Drip Irrigation. Water 2018, 10, 970. [CrossRef]

76. EuropeAid/128500C/ACT/Multi-Annex A-Grant Application Form. Generation and adaptation of improved agricultural technologies to mitigate climate change-imposed risks to food production within vulnerable smallholder farming communities in Western Pacific countries, Papua New Guinea (PNG), Solomon Islands (SI) and Vanuatu (Vu) Papua New Guinea (PNG), Solomon Islands (SI) and Vanuatu (Vu). 2011, Global Programme on Agricultural Research for Development (ARD 2009-2010). Available online: https:/ /www.nab.vu/projects/nari-agriculture-project-0.

77. Bailey, J. Supplying Water or Domestic Usage; National Agricultural Research Institute (NARI): Lee, PNG Papua Newguinea, 2009.

78. Loiskandl, W. Personal Photo Documentation; Foto Documentation Done during Innovation Days at the National Agricultural Research Institute (NARI); NARI: Lee, Papua Newguniea, 2011.

79. Molden, D. A water-productivity framework for understanding and action. In Water Productivity in Agriculture: Limits and Opportunities for Improvement; Kijne, J.W., Barker, R., Molden, D., Eds.; International Water Management Institute: Colombo, Sri Lanka, 2003; pp. 1-18.

80. Geerts, S.; Raes, D. Deficit Irrigation as an On-Farm Strategy to Maximize Crop Water Productivity in Dry Areas. Agric. Water Manag. 2009, 96, 1275-1284. [CrossRef]

81. Hatfield, J.L.; Dold, C. Water-Use Efficiency: Advances and Challenges in a Changing Climate. Front. Plant Sci. $2019,10,103$. [CrossRef]

82. Mpanga, I.K.; Idowu, O.J. A Decade of Irrigation Water use trends in Southwestern USA: The Role of Irrigation Technology, Best Management Practices, and Outreach Education Programs. Agric. Water Manag. 2021, 243, 106438. [CrossRef]

83. Fereres, E.; Soriano, M.A. Deficit irrigation for reducing agricultural water use. Special issue on 'Integrated approaches to sustain and improve plant production under drought stress'. J. Exp. Bot. 2007, 58, 147-159. [CrossRef]

84. English, M.; Raja, S.N. Perspectives on deficit irrigation. Agric. Water Manag. 1996, 32, 1-14. [CrossRef]

85. Montazar, A.; Bachie, O.; Corwin, D.; Putnam, D. Feasibility of Moderate Deficit Irrigation as a Water Conservation Tool in California's Low Desert Alfalfa. Agronomy 2020, 10, 1640. [CrossRef]

86. McCarthy, M.G.; Loveys, B.R.; Dry, P.R.; Stoll, M. Regulated deficit irrigation and partial rootzone drying as irrigation management techniques for grapevines. In Deficit Irrigation Practices; Food and Agricultural Organization of the United Nations (FAO): Rome, Italy, 2002; pp. 79-88.

87. Romero-Trigueros, C.; Bayona Gambín, J.M.; Nortes Tortosa, P.A.; Alarcón Cabañero, J.J.; Nicolás, E. Determination of Crop Water Stress Index by Infrared Thermometry in Grapefruit Trees Irrigated with Saline Reclaimed Water Combined with Deficit Irrigation. Remote Sens. 2019, 11, 757. [CrossRef]

88. Romero-Trigueros, C.; Nortes, P.A.; Alarcón, J.J.; Hunink, J.E.; Parra, M.; Contreras, S.; Droogers, P.; Nicolás, E. Effects of saline reclaimed waters and deficit irrigation on Citrus physiology assessed on by UAV remote sensing. Agric. Water Manag. 2017, 183, 60-69. [CrossRef] 
89. Australian Government Department of Agriculture, Fisheries and Forestry. Available online: http:/ /www.connectedwater.gov. au/this_website.html (accessed on 2 November 2011).

90. Grubinger, H. Wasserschatz und Lebensader Marchfeldkanal: 10 Jahre Flutung des Marchfeldkanals-Beginn der Grundwasserbewirtschaftung; Neudorfer, W., Ed.; Herausgeber: Betriebsgesellschaft Marchfeldkanal: Deutsch-Wagram, Austria, 2002; ISBN 978-3-900827-11-3.

91. Alam, M.F.; Pavelic, P. Underground Transfer of Floods for Irrigation (UTFI): Exploring Potential at the Global Scale; IWMI Research Report 176; International Water Management Institute (IWMI): Colombo, Sri Lanka, 2020; p. 58. [CrossRef]

92. Farooq, A.M.; Omed, Y.; Raza, A.M.; Ismail, S. Groundwater Dams, General Characteristics and Historical Development; JFET 23 University of Engineering \& Technology: Lahore, Pakistan, 2016.

93. Pratt, K.B. Water banking: A new tool for water management. Colo. Lawyer 1994, 23, 595-597.

94. Singletary, L. Water Banking: What Is It and How Does It Work? Fact Sheet 98-09, Western Resource Issues Education Series No. 6. 2009. Available online: http:/ / www.unce.unr.edu/publications/files/ho/other/fs9809.pdf (accessed on 1 July 2009). 